\title{
The external morphology of the third and fourth zoeal stages of the blue crab, Callinectes sapidus Rathbun
}

\section{Sewell H. Hopkins}

Virginia Fisheries Laboratory

Follow this and additional works at: https://scholarworks.wm.edu/vimsarticles

Part of the Aquaculture and Fisheries Commons

\section{Recommended Citation}

Hopkins, Sewell H., "The external morphology of the third and fourth zoeal stages of the blue crab, Callinectes sapidus Rathbun" (1944). VIMS Articles. 1847.

https://scholarworks.wm.edu/vimsarticles/1847

This Article is brought to you for free and open access by the Virginia Institute of Marine Science at W\&M ScholarWorks. It has been accepted for inclusion in VIMS Articles by an authorized administrator of W\&M ScholarWorks. For more information, please contact scholarworks@wm.edu. 


\title{
THE EXTERNAL MORPHOLOGY OF THE THIRD AND FOURTH ZOEAL STAGES OF THE BLUE CRAB, CALLINECTES SAPIDUS RATHBUN ${ }^{1}$
}

\author{
SEWELL H. HOPKINS
}

Agricultural and Mechanical College of Texas and Virginia Fisheries Laboratory

For the past two years, workers at the Virginia Fisheries Laboratory, Williamsburg, have been attempting to rear larvae of the commercially important blue crab from the egg through all zoeal stages. In 1941 Dr. Margaret S. Lochhead worked out a successful method of hatching the eggs (Lochhead, Lochhead and Newcombe, 1942) and reared the larvae to the "second zoea" stage. During the summers of 1942 and 1943 this work was continued by Mrs. Mildred Sandoz and Miss Rosalie Rogers, who succeeded in rearing a number of individuals to the "third zoea" stage. The anatomy of the first and second zoeal stages was described in detail by Hopkins (1943). Churchill (1942) described five zoeal stages found in plankton tows at the mouth of Chesapeake Bay. Churchill's first and second zoeae seem to be identical with those reared from blue crab eggs at the Virginia Fisheries Laboratory, but his third zoea is markedly different from the third zoea reared at this laboratory, as reported by Sandoz and Hopkins (1944).

It is now realized, by the agencies concerned with regulation of the crab fishery in Chesapeake Bay, that a more detailed knowledge of the biology of the crab is necessary. Studies of the numbers and seasonal and geographic distribution of larvae in all stages are important means of locating the breeding grounds and determining the length of the larval period, the migrations of the larvae, the percentage of survival under natural conditions, etc. Obviously these studies will be worthless unless the blue crab larvae are correctly identified, and distinguished from the other species of the same family (Portunidae) found in this region. The following paragraphs attempt to give an accurate and detailed description of all features which may be of importance in separating larvae of different species.

A number of individuals in the "fourth zoea" stage have been found in plankton tows made by the Virginia Fisheries Laboratory in the mouth of the Bay near Cape Henry. These are very similar to the blue crab "third zoea" raised in the laboratory and found in plankton, but quite different from Churchill's "fourth zoea" (which was also found in our tows).

The first and second zoeal stages have been restudied, and a few minor corrections of my 1943 description seem necessary. In the first zoea, there are six setae on the endopodite of the first maxilla, two in one group and four in the other. In the second zoea, there are normally three apical setae on the scaphognathite of the second maxilla, although only two can be seen in some specimens. The shorter seta on the fourth segment of the endopodite of the first maxilliped is usually longer than indicated in my 1943 report.

${ }_{1}^{1}$ Joint contribution from the Virginia Fisheries Laboratory of the College of William and Mary and Commission of Fisheries (Number 20): and from the A. and M. College of Texas. 


\section{The Third Zoea}

Three specimens reared in the laboratory and six found in plankton tows (Cape Henry, August 14, 1941) were dissected and mounted in glycerine. In addition, a number of specimens from plankton and one specimen reared in the laboratory were mounted and studied entire, and still others were studied in formalin without mounting. Even after the most detailed study, no difference could be found between laboratory-reared and plankton specimens, except that one laboratory-reared specimen seemed to have moulted precociously (the telson lacked the fourth or inner pair of setae, the second maxilla was of the second zoea type, and the size was below normal, although the maxillipeds each bore eight swimming hairs).

The total length of the body is difficult to measure accurately because of the bent position of most specimens, but varies between 1.40 and $1.65 \mathrm{~mm}$., measured from front of carapace between eyes to tips of telson. The carapace is exactly as in the second zoea except for larger size and the presence of a single (occasionally two) seta with setules on the posterior edge of the carapace. The dorsal spine is 0.40 to $0.50 \mathrm{~mm}$. long, the lateral spines are 0.09 to $0.10 \mathrm{~mm}$., and the rostrum is 0.33 to $0.36 \mathrm{~mm}$. (measured from lower edges of bases of eyestalks). The eyes have very short stalks and are 0.21 to $0.26 \mathrm{~mm}$. in diameter (Figs. 1 and 2).

The antennule is unchanged from its form in the second zoea except that the setae or aesthetes are less uniform in width; the largest aesthete is about twice as wide as the second, the second is almost twice as wide as the third, and the third is about twice as wide as the fourth; there is also a very short bristle or seta which usually cannot be seen. The peduncle of the antennule is 0.12 to $0.15 \mathrm{~mm}$. long and the length of the longest aesthete is about $0.20 \mathrm{~mm}$. (Fig. 3).

The antenna is 0.30 to $0.35 \mathrm{~mm}$. long. The spinous process bears 12 to 18 hooklike spines on each side. The exopodite is about $0.01 \mathrm{~mm}$. long and bears two setae of unequal length, the longer 0.03 to $0.04 \mathrm{~mm}$. long. There is a very slight ridge or bulge on the antenna near the exopodite which represents the first rudiment of the endopodite.

The labrum bears a distinct chromatophore. The mandible is 0.12 to $0.19 \mathrm{~mm}$. long and 0.08 to $0.11 \mathrm{~mm}$. wide, and bears a very large chromatophore usually divided into three parts.

The maxillule or first maxilla is 0.16 to $0.22 \mathrm{~mm}$. long, from base to end of endopodite. The outer edge of the basipodite bears a seta about $0.04 \mathrm{~mm}$. long. The distal (basal) endite of the protopodite bears eight setae and the proximal (coxal) endite bears six or seven setae. The endopodite is two-segmented; the

\section{Plate I}

The third zoeal stage of Callinectes sapidus. All figures are camera lucida drawings Scale line A represents $0.5 \mathrm{~mm}$. in Figures 1 and 2; scale line B represents $0.2 \mathrm{~mm}$. in Figures 3-7.

FIGURE 1. Third zoea reared from egg in laboratory, slightly flattened under cover glass.

FIgURE 2. Third zoea from plankton tow, Cape Henry.

FIGURE 3. Antennule, third zoea from plankton.

FIGURE 4. First maxilla, third zoea reared in laboratory.

FIGURE 5. Second maxilla, third zoea from plankton.

FIGURE 6. Endopodite of first maxilliped, third zoea reared in laboratory.

FIGURE 7. Endopodite of second maxilliped, third zoea reared in laboratory. 
THIRD AND FOURTH ZOEAE OF BLUE CRAB

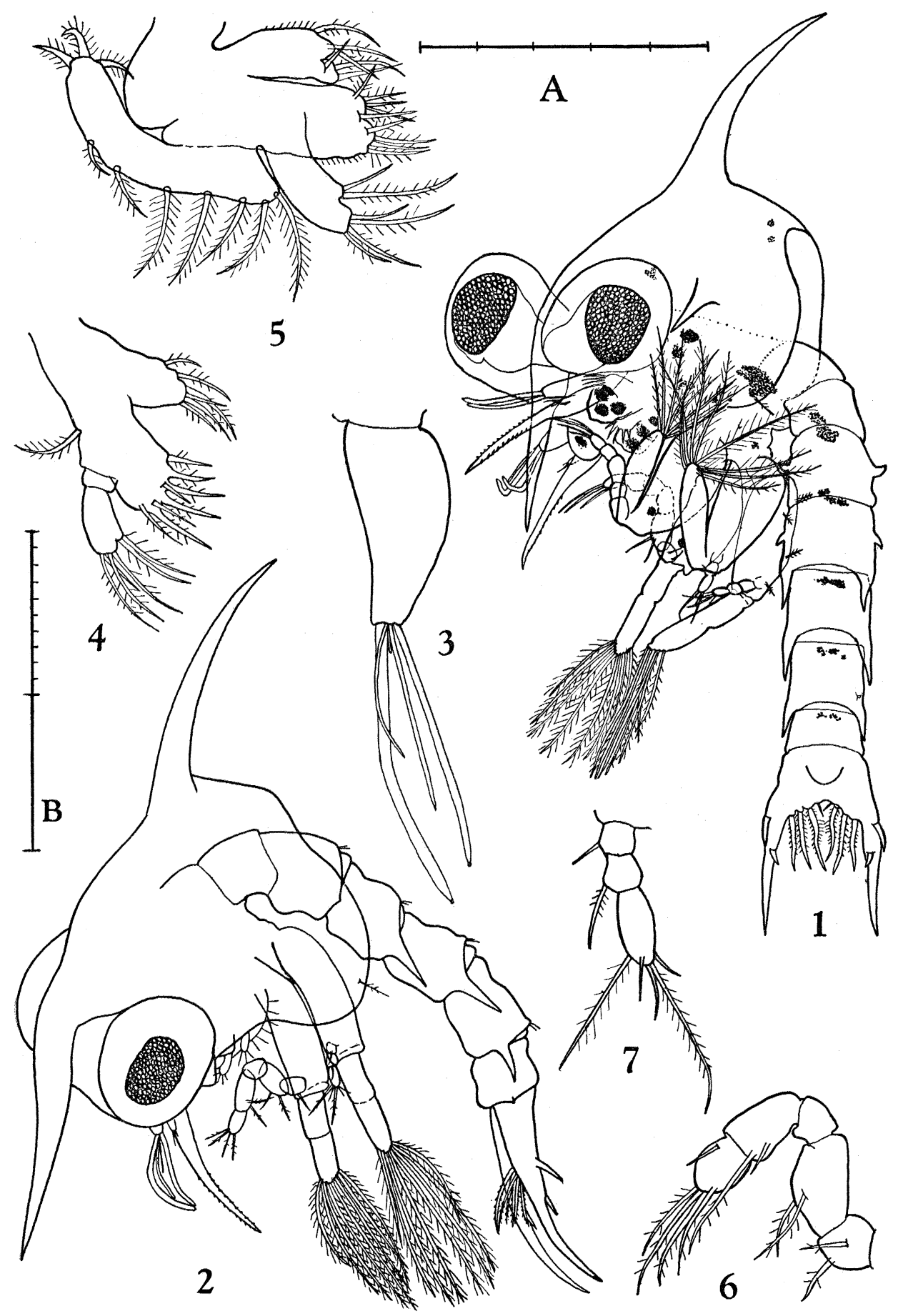

PLATE I 
distal segment is bifurcated and bears two groups of setae, four in one group and two in the other. The setae on the basal and coxal endites are 0.03 to $0.06 \mathrm{~mm}$. long and those on the endopodite are 0.04 to $0.08 \mathrm{~mm}$. long; all setae on the first maxilla have setules (Fig. 4).

The second maxilla seems to be subject to considerable variation in size and number of setae. The length of the second maxilla varies from 0.12 to $0.17 \mathrm{~mm}$., measured from the base to the tip of the endopodite. The scaphognathite measures from 0.13 to $0.16 \mathrm{~mm}$. through its longest dimension, and bears seven or eight setae along the distal part of the outer margin plus three to five apical setae around the proximal tip, making a total of ten to twelve setae. The endopodite has a single segment with bilobed tip bearing six setae in two groups, two in one group and four in the other. The basal and coxal endites are both bilobed; the distal (basal) endite bears nine setae and the proximal (coxal) one bears six or seven setae. All setae on the second maxilla bear setules and there are also setules around the margins of the endites (Fig. 5).

The basipodite of the first maxilliped is 0.20 to $0.27 \mathrm{~mm}$. long; its posterior side bears ten setae with setules, and there is a very distinct chromatophore near its distal end. The endopodite is 0.18 to $0.23 \mathrm{~mm}$. long, and has five segments; the first (proximal) segment bears two setae, the next bears two, the third has none, the fourth bears two, and the fifth bears five setae, four terminal and one short lateral seta (Fig. 6). The exopodite is divided into two segments; its length is 0.16 to $0.18 \mathrm{~mm}$. ; the eight terminal setae or "swimming hairs" are of unequal lengths, varying from 0.13 to $0.23 \mathrm{~mm}$.

The basipodite of the second maxilliped is 0.20 to $0.24 \mathrm{~mm}$. long and bears four setae with setules near its posterior margin; there is no chromatophore in the basipodite, but there is a rather small chromatophore in the coxopodite. The endopodite is 0.06 to $0.09 \mathrm{~mm}$. long and consists of three segments; the first (proximal) and second segment each bear one seta and the third bears five unequal terminal setae (Fig. 7). The exopodite is 0.18 to $0.23 \mathrm{~mm}$. long, is divided into two segments, and bears eight terminal setae or "swimming hairs" of unequal lengths, 0.15 to $0.27 \mathrm{~mm}$.

The abdomen is 1.05 to $1.20 \mathrm{~mm}$. long and has six segments, not counting the telson. The lateral spines or hooks on the second and third segments are exactly as in the second zoea. The third, fourth, and fifth segments have lateral spines projecting posteriad from the posterior margin of each segment. The second, third, fourth, and fifth segments each have a pair of dorsal setae projecting from the posterior margin, but there is no sign of a dorsal spine on any segment. The first

\section{Plate II}

The fourth zoeal stage of Callinectes sapidus. All figures are camera lucida drawings. Scale line A represents $0.5 \mathrm{~mm}$. in Figure 8; scale line B represents $0.2 \mathrm{~mm}$. in Figures $9-14$.

Figure 8. Fourth zoea from plankton tow, Cape Henry.

Figure 9. Antennule.

Figure 10. Antenna.

FIGURE 11. First maxilla.

Figure 12. Second maxilla.

FIGURE 13. Endopodite of first maxilliped.

FIGURE 14. Endopodite of second maxilliped. 


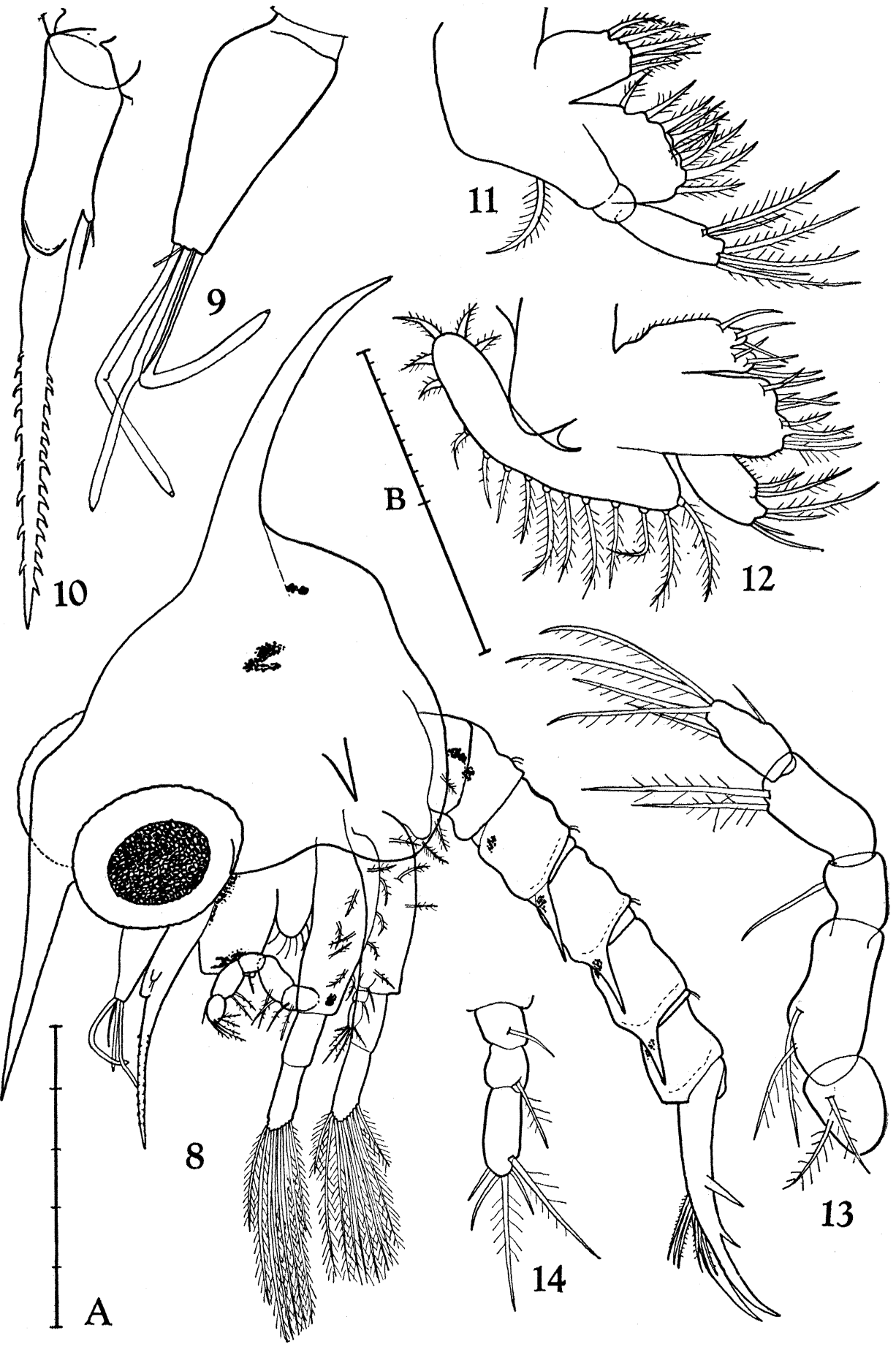


abdominal segment bears a large median chromatophore; each of the other segments bears a chromatophore lying across the extreme anterior end near the ventral surface. Except for slightly larger size, the telson is unchanged from its condition in the second zoea; that is, the dorsal side of each furcus bears a large spine directed dorsolaterally, and a smaller spine, farther back, directed dorsally, and the inner side of each furcus bears close to its base a small spine without setules in addition to the original three setae with setules (Fig. 1).

The chromatophores probably cannot be described accurately without using living specimens, but the following chromatophores have been seen in the best preserved specimens: (1) one chromatophore in the front of the head, between the eyes; (2) one chromatophore dorsal to the anterior part of the alimentary canal; (3) a pair of large chromatophores dorsal to the gut in the posterior part of the cephalothorax; (4) a pair of chromatophores just ventral to the anterior part of the alimentary canal ; (5) a small chromatophore, not always visible, below the base of the dorsal carapacial spine; (6) a large chromatophore in the center of the first abdominal segment; (7) chromatophores in the ventral anterior margin of the third, fourth, fifth, and sixth abdominal segments; (8) a large chromatophore in the labrum; (9) a large chromatophore in each mandible; (10) a chromatophore in the distal end of the basipodite of each first maxilliped; (11) a chromatophore in the coxopodite of each second maxilliped.

\section{The Fourth Zoea}

Several specimens which are tentatively identified as the "fourth zoea" of the blue crab were found in surface plankton tows near Cape Henry, August 14, 1941. Five of these specimens have been studied in formalin solution, and two have been dissected for more detailed study of appendages. These specimens are identical with the third zoea of the blue crab except for larger size, a better developed endopodite bud on the antenna, additional setae on the maxillae and maxillipeds, and more setae on the posterior edge of the carapace. Identification of this zoea should, of course, be checked by comparison with laboratory-reared fourth zoeae when these can be obtained, but, in the meantime, I have little or no doubt that this is actually the fourth zoea of the blue crab.

The length of the body, from midway between eyes to tips of the telson, is 1.75 to $1.95 \mathrm{~mm}$. The dorsal spine on the carapace is 0.54 to $0.60 \mathrm{~mm}$. long and the lateral spines are about $0.12 \mathrm{~mm}$. long. The length of the rostrum is from 0.45 to $0.50 \mathrm{~mm}$. The eyes are about $0.35 \mathrm{~mm}$. in diameter. The posterior edge of the carapace on each side bears three large setae with setules (Fig. 8).

The antennule is almost exactly as in the third zoea; the peduncle is $0.16 \mathrm{~mm}$. long and the longest aesthete is $0.20 \mathrm{~mm}$. (Fig. 9). The antenna is from 0.35 to $0.42 \mathrm{~mm}$. long and is unchanged from the third zoeal stage except that the bud of the endopodite is now very distinct (Fig. 10) ; it is noteworthy that the exopodite is still of exactly the same form as in the first zoea. The labrum and mandible are as in the third zoea except for slightly larger size. The maxillule or first maxilla differs from the third zoeal stage only in slightly larger size and in having nine or ten setae on the distal (basal) endite where the third zoea had eight (Fig. 11). The scaphognathite of the second maxilla bears about sixteen setae, with only a slight gap between the setae of the outer margin and the apical setae, which are now similar 
in form. The basal and coxal endites of the second maxilla are as in the third zoea except that the distal (basal) endite bears nine or ten setae and the proximal (coxal) one has seven (Fig. 12).

The first maxilliped bears eight setae or "swimming hairs" on the exopodite. The endopodite is five-segmented; the first segment bears two setae, the second bears two, the third bears one (lacking in some specimens), the fourth has two, and the terminal segment bears six setae of which four are terminal (Fig. 13). The basipodite of the first maxilliped bears ten setae, located mostly along its posterior edge. The basipodite is $0.28 \mathrm{~mm}$. long, the exopodite is 0.23 to $0.26 \mathrm{~mm}$., and the endopodite is 0.25 to $0.31 \mathrm{~mm}$. The longest seta on the exopodite is 0.32 $\mathrm{mm}$. long. As in previous stages, there is a chromatophore in the distal end of the basipodite (Fig. 8).

The second maxilliped bears ten terminal setae on the exopodite. The endopodite is three-segmented; the first and second segments each bear one seta and the terminal segment has five setae (Fig. 14). The basipodite bears four setae and contains no chromatophore, but the coxopodite does have a chromatophore. The basipodite is $0.30 \mathrm{~mm}$. long, the exopodite $0.24 \mathrm{~mm}$., and the endopodite 0.09 to $0.11 \mathrm{~mm}$. The longest seta on the exopodite is 0.31 to $0.34 \mathrm{~mm}$. long.

The abdomen, including the telson, is identical in every detail with the abdomen of the third zoea, except for larger size.

\section{Discussion}

Churchill $(1941,1942)$ has described five zoeal stages which he assigned to Callinectes sapidus. His first zoea and second zoea do belong to this species; they agree with our laboratory-reared zoeae in every detail except that Churchill apparently overlooked the little dorsal spine on each furcus of the telson, which is present in all blue crab zoeae from the first. However, Churchill's third and fourth zoeae, and presumably his fifth zoea also, belong to a different species of crab and have nothing to do with $C$. sapidus. Churchill's third zoea is slightly larger than our laboratory-reared blue crab third zoea, but the most striking differences are the presence of prominent dorsal spines on the fifth abdominal segment (lacking in $C$. sapidus) and the much greater length of the antennal exopodite (which in $C$. sapidus is unchanged from the second zoeal stage). Churchill's third zoea has six swimming hairs on the exopodite of the first maxilliped, and seven on the second, while $C$. sapidus has eight on each maxilliped. There are also minor differences, including the number of setae on the carapace, the degree of development of the appendages following the second maxilliped, and perhaps the numbers of setae on the endopodites of the maxillipeds.

I did not find Churchill's third zoea in my plankton tows, but I did find one specimen of his fourth zoea (in a surface tow off Ocean View, Va., Aug. 14, 1941) and can confirm the accuracy of his excellent figure and description of this stage. Churchill's fourth zoea is much more robust than the fourth zoea which I have assigned to $C$. sapidus; the larger size is obvious to the naked eye. In addition to the possession of dorsal spines on the fifth abdominal segment and the elongated antennal exopodite, his species differs from mine by having seven (instead of three) setae on the posterior edge of the carapace, nine swimming hairs (instead of ten) on the exopodite of the second maxilliped, and greater development of the buds of 
appendages posterior to the second maxilliped. The distal pair of spines on the furci of the telson are much smaller than the corresponding spines in blue crab zoeae and are on the inner side of the furci rather than the dorsal side as in $C$. sapidus. Both maxillipeds contain chromatophores in the basipodites in Churchill's species, while only the first maxillipeds of $C$. sapidus have chromatophores in the basipodite.

Churchill's description of five zoeal stages which he assigned to $C$. sapidus was based entirely on specimens found in plankton, with the exception of the first zoea. The Virginia Fisheries Laboratory has hatched thousands of blue crab eggs in the laboratory and has reared a few specimens through the second and third zoeal stages, so that the identity of these stages is known beyond question. The identity of the fourth zoea, described and assigned to C. sapidus in the present paper, has not been confirmed in this way.

It is certain that Churchill's third zoea does not belong to C. sapidus; probably it is a zoeal stage of some other crab of the family Portunidae. The zoeal stages of Ovalipes ocellatus, Arenaeus cribrarius, Bathynectes superba, and Callinectes ornatus (species which live in or near the mouth of Chesapeake Bay) have never been described, so it is possible that Churchill's species belongs to one of these. It seems probable that his fourth and fifth zoeae belong to the same species as his third zoea, and it is practically certain that they do not belong to Callinectes sapidus. The zoeae of several species of Portunus described by Lebour (1928) have a long antennal exopodite like Churchill's zoea, but none of them have dorsal spines on the fifth (or any other) abdominal segment.

It seems probable that $C$. sapidus has a fifth zoeal stage which has not yet been seen by anyone.

\section{LITERATURE CITED}

Churchill, E. P., 1941. The zoeal stages of the blue crab, Callinectes sapidus. Anat. Rec., 81 (Suppl.) : 37-38 (Abstract).

Churchill, E. P., 1942. The zoeal stages of the blue crab, Callinectes sapidus Rathbun. Publ. No. 49, Chesapeake Biol. Lab.

Hopkins, S. H., 1943. The external morphology of the first and second zoeal stages of the blue crab, Callinectes sapidus Rathbun. Trans. Amer. Micros. Soc., 62: 85-90.

Lebour, M., 1928. The larval stages of the Plymouth Brachyura. Proc. Zool. Soc. London, July, 1928: 473-560.

Lochiead, M. S., J. H. Lochiead, and C. L. Newcombe, 1942. Hatching of the blue crab, Callinectes sapidus Rathbun. Science, $95: 382-383$.

Loch head, M. S., AND C. L. NEwCombe, 1942. Methods of hatching eggs of the blue crab. Virginia Jour. Sci., 3: 76-86.

Sandoz, M., and S. H. Hopkins, 1944. Zoeal larvae of the blue crab Callinectes sapidus Rathbun. Jour. Wash. Acad. Sci., 34: 132-133. 